\title{
CORRIGENDUM
}

\section{Natural killer cell lymphoma shares strikingly similar molecular features with a group of non-hepatosplenic $\gamma \delta$ T-cell lymphoma and is highly sensitive to a novel aurora kinase $A$ inhibitor in vitro}

J Iqbal, DD Weisenburger, A Chowdhury, MY Tsai, G Srivastava, TC Greiner, C Kucuk, K Deffenbacher, J Vose, L Smith, WY Au, S Nakamura, M Seto, J Delabie, F Berger, F Loong, Y-H Ko, I Sng, X Liu, TP Loughran, J Armitage and WC Chan for the International Peripheral T-cell Lymphoma Project

Leukemia (2011) 25, 1377; doi:10.1038/leu.2011.102

Correction to: Leukemia (2011) 25, 348-358; doi:10.1038/ leu.2010.255

Since the publication of this paper, the authors have noticed an error in Supplementary Table 1.

The ethnicity of the Jurkat cell line was incorrectly listed as Japanese, when it should have been listed as Caucasian.
The corrected supplementary table can be accessed via the online version of this corrigendum.

The authors would like to apologise for any inconvenience this may have caused. 